\title{
${ }^{1} \mathrm{H}-\mathrm{AND}{ }^{13} \mathrm{C}-\mathrm{NMR}$ STRUCTURAL CHARACTERIZATION OF ASPHALTENES FROM VACUUM RESIDUA MODIFIED BY THERMAL CRACKING
}

\section{CARACTERIZACIÓN ESTRUCTURAL POR RMN- ${ }^{1} H$ y ${ }^{13}$ C DE ASFALTENOS DE RESIDUOS DE VACÍO MODIFICADOS POR RUPTURA TÉRMICA}

Juan-Carlos Poveda ${ }^{* 1}$, Daniel-Ricardo Molina ${ }^{1}$ and Edgar-Francisco Pantoja-Agreda²

'Universidad Industrial de Santander, Bucaramanga, Santander, Colombia

${ }^{2}$ Corporación para la Investigación de la Corrosión, Piedecuesta, Santander, Colombia

e-mail: jcpoveda@uis.edu.co

(Received: Jan. 08, 2014; Accepted: Jun. 17, 2014)

\section{ABSTRACT}

125 - and ${ }^{13} \mathrm{C}-\mathrm{NMR}$ data were used to characterize asphaltenes and to follow their chemical changes when they were exposed to thermal cracking under different thermal conditions $(673,693$ and $713 \mathrm{~K})$, and treatment times $(10,20$ and 30 minutes). Samples of asphaltenes were obtained from a Vacuum Residue (VR) of a mixture of Colombian crude oils. Samples were previously characterized by elemental analysis. Since the characterization of the aromatic substructure is important for this work, special attention was given to those regions in the ${ }^{1} \mathrm{H}$ - and ${ }^{13} \mathrm{C}-\mathrm{NMR}$ spectra that showed the main changes: p.e. methyl hydrogens -in gamma position or more- to aromatic units $\mathrm{H}_{\mathrm{CH}_{3}}^{\gamma}$; methyl hydrogens -in beta positions- to aromatics units $\mathrm{H}_{\mathrm{CH}_{3}}^{\beta}$; methylene hydrogens -in beta position- to aromatics $\mathrm{H}_{\mathrm{CH}_{2}}^{\beta}$; hydrogens -in naphthenic units beta- to aromatics $\mathrm{H}_{N}^{\beta}$; hydrogens -in paraffinic and alpha position naphthenic structures-in - to aromatics $\mathrm{H}_{\mathrm{P}, \mathrm{N}}^{\alpha}$; hydrogens in monoaromatic units $\mathrm{H}_{\mathrm{Ar}_{r} \text {; }}^{\mathrm{ma}}$ hydrogens in polyaromatics $\mathrm{H}_{\mathrm{Ar}}^{\mathrm{pa}}$; carbons in methyl groups $\mathrm{C}_{\mathrm{CH}_{3}}$; carbons in methyl groups -in alpha position- to aromatics $\mathrm{C}_{\mathrm{CH}_{3}}^{\mathrm{Ar}}$; protonated aromatic carbons $\mathrm{C}_{\mathrm{Ar}}^{\mathrm{H}}$; pericondensed aromatic carbons $\mathrm{C}_{\mathrm{AAA}}$; aromatic carbons linked to methyl groups; $\mathrm{C}_{\mathrm{Ar}}^{\mathrm{CH}_{3}}$ catacoWndensed aromatic carbons $C_{A A}$ and aromatic carbons linked to paraffinic or naphthenic structures $C_{A r}^{S}$.

Keywords: Asphaltenes, NMR spectroscopy, Thermal cracking.

How to cite: Poveda, J. C., Molina, D. R. \& Pantoja-Agreda, E. F. (2014). ${ }^{1} \mathrm{H}$ - and ${ }^{13} \mathrm{C}-\mathrm{NMR}$ structural characterization of asphaltenes from vacuum residua modified by thermal cracking. CT\&F - Ciencia, Tecnología y Futuro, 5(4), 49-60.

*To whom correspondence should be addressed 


\section{RESUMEN}

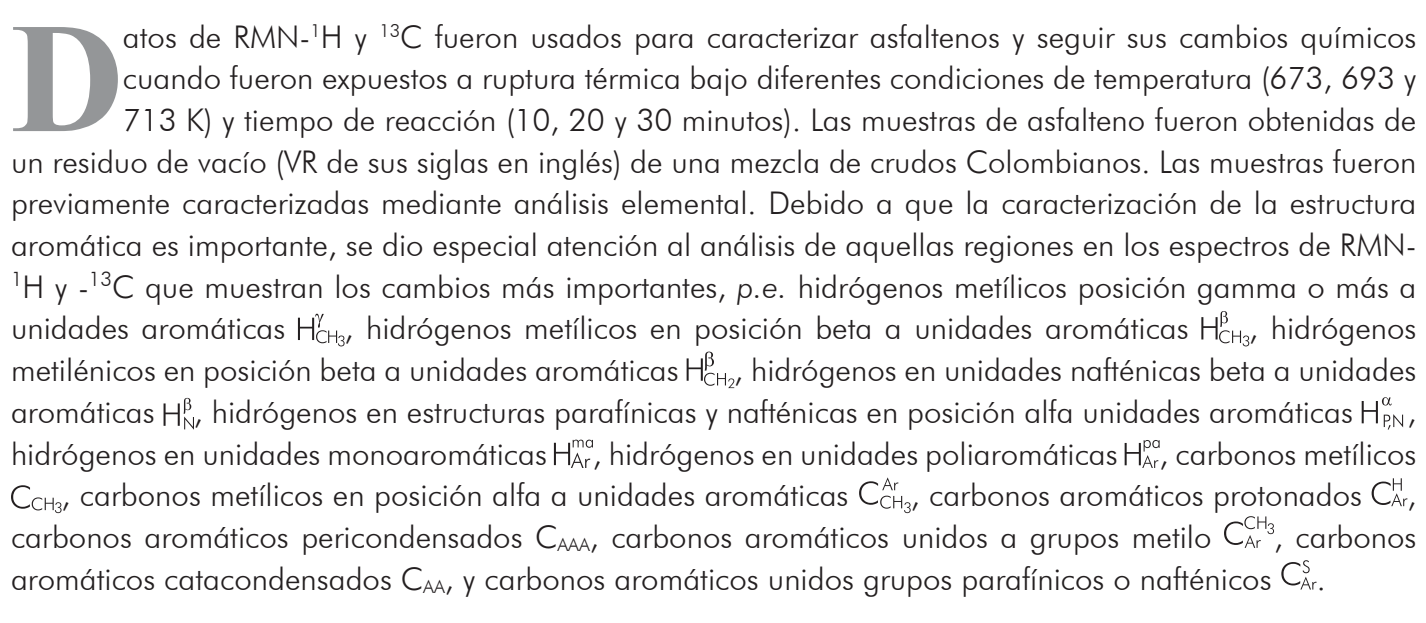

Palabras clave: Asfaltenos, Espectroscopia de RMN, Craqueo térmico.

\section{RESUMO}

$\mathrm{D}$

ados de $\mathrm{RMN}-{ }^{1} \mathrm{H}$ e de ${ }^{13} \mathrm{C}$ foram usados para caracterizar asfaltenos e seguir suas mudanças químicas quando expostos a ruptura térmica sob diferentes condições de temperatura $(673,693$, $713 \mathrm{~K})$ e de tempo de reação $(10,20,30$ minutos). As amostras de asfalteno foram obtidas de um resíduo de vácuo (VR, por sua sigla em inglês) de uma mistura de crus Colombianos. As amostras foram previamente caracterizadas mediante análise elementar. Devido a que a caracterização da estrutura aromática é importante, foi dada especial atenção à análise daquelas regiões nos espectros de $\mathrm{RMN}-{ }^{1} \mathrm{H}$ e de ${ }^{13} \mathrm{C}$ que mostram as mudanças mais importantes, por exemplo, hidrogênios metílicos em posição gama ou mais a unidades aromáticas $\mathrm{H}_{\mathrm{CH}_{3}}^{\gamma}$, hidrogênios metílicos em posição beta a unidades aromáticas $\mathrm{H}_{\mathrm{CH}_{3}}^{\beta}$, hidrogênios metilênicos em posição beta a unidades aromáticas $\mathrm{H}_{\mathrm{CH}_{2}}^{\beta}$, hidrogênios em unidades naftênicas beta a unidades aromáticas $H_{N}^{\beta}$, hidrogênios em estruturas parafínicas e naftênicas em posição alfa a unidades aromáticas $H_{p, N}^{\alpha}$, hidrogênios em unidades monoaromáticas $H_{A_{r},}^{m a}$ hidrogênios em unidades poliaromáticas $H_{A r}^{p a r}$ carbonos metílicos $\mathrm{C}_{\mathrm{CH}_{3}}$ carbonos metílicos em posição alfa a unidades aromáticas $\mathrm{C}_{\mathrm{CH}_{3}}^{\mathrm{Ar}}$ carbonos aromáticos protonados $C_{A r}^{H}$, carbonos aromáticos pericondensados $C_{A A A}$, carbonos aromáticos unidos a grupos metila $\mathrm{C}_{\mathrm{Ar}}^{\mathrm{CH}_{3}}$, carbonos aromáticos catacondensados $\mathrm{C}_{\mathrm{AA}}$, e carbonos aromáticos unidos a grupos parafínicos ou naftênicos $C_{A r}^{S}$.

Palavras-chave: Asfaltenos, Espectroscopia de RMN, Craqueamento térmico. 


\section{INTRODUCTION}

Structural characterization of crude oils and their fractions is crucial in determining quality and refined products over the entire range of the fractions. From a global perspective, the production of heavy crude oils has dramatically increased, and analytical tools producing information regarding the chemical structures play a key role in the petrochemical industry.

The chemical characterization of crude oils and their fractions includes the use of different spectroscopic techniques (Andersen, Oluf Jensen \& Speight, 2005; Ballard-Andrews, Guerra, Mullins \& Sen, 2006; Eyssautier et al., 2011; Hurtado, Gámez \& MartínezHaya, 2010; Rodríguez et al., 2006). Special attention has been given to proton and carbon nuclear magnetic resonance spectroscopy, ${ }^{1} \mathrm{H}$ and ${ }^{13} \mathrm{C}-\mathrm{NMR}$ (Cantor, 1978; Dickinson, 1980; Knight, 1967; Majumdar, Gerken, Mikula \& Hazendonk, 2013). Since its origins, NMR spectroscopy has been used to characterize petroleum fractions in both lighter fractions -such as jet fuel and gas oils- as well as in heavy fractions -such as VRs, crude oils, tar pitches, resins, and asphaltenes-. NMR data provide information regarding the relative amount of structural composition in a sample. In conjunction with elemental analysis and average molecular weight data, it is possible to obtain quantitative information about the different types of protons and carbons present. This chemical characterization is defined in terms of average molecular parameter, AMPs, and provides information for representing the bulk sample structural properties (Gillet, Delpuech, Valentin \& Escalier, 1980; Gupta, Dogra, Kuchhal \& Kumar, 1986; Hirsch \& Altgelt, 1970; Poveda \& Molina, 2012; Rongbao; Zengmin \& Bailing, 1988; Brown \& Ladner, 1960; Rousseau \& Fuchs, 1989; Yokoyama et al., 1981).

${ }^{13} \mathrm{C}-\mathrm{NMR}$ experiments are useful to obtain information about backbone carbon structure in both medium and heavy fractions, information that cannot be obtained from ${ }^{1} \mathrm{H}-\mathrm{NMR}$. Since it is impossible to distinguish each compound in heavy crude oils and their fractions, and quantitatively predict the presence of a particular compound using NMR spectroscopy, it is necessary to apply chemical characterization. This is done on the basis of the main chemical groups, and by using specific regions in the NMR spectra. The
${ }^{13} \mathrm{C}$-NMR experiments require long data acquisition times (hours), because a large number of scans and large pulse delays are needed, as well as relaxation reagents. In data analysis, the primary problem is matching specific areas with specific structural fragments. In this regard, several pulse sequences have been applied to specify the assignments in the spectra, including 1D and 2D experiments such as the Distortion Enhancement Proton Test (DEPT); Proton-Proton COrrelation SpectroscopY (COSY); Heteronuclear Multi Quantum Coherence (HMQC); Heteronuclear Multiple Bond Correlation (HMBC) (Dosseh, Rousseau \& Fuchs, 1991; Doan, Gillet, Blondel \& Beloiel, 1995; Väänänen, Koskela, Hiltunen \& Ala-Korpela, 2002), and Heteronuclear Single Quantum Coherence (HSQC) (Majumdar et al., 2013).

Structural characterization of the different fractions of crude oils or fractions obtained in refinery processes -using NMR spectroscopy- may help understand the changes that occur at the molecular level when fractions are subjected to processes such as thermal cracking, catalytic hydrogenation, and pyrolysis, among others. Structural characterization of heavy fractions received particular attention because they cannot be characterized by conventional analytical techniques. Structural characterization helps understand how the operating conditions of a process unit can affect the molecular structure of a cut or fraction.

In this work, we use the NMR spectroscopy and area assignments reported by the authors (Poveda \& Molina, 2012) to analyze the structural changes of asphaltenes obtained from a vacuum residue thermally cracked at three reaction times (10,20 and 30 minutes) and different temperatures $(673,693$ and 713 K). Similar experimental conditions were previously reported by other authors (Yasar, Trauth \& Klein, 2001; Ancheyta, Trejo \& Rana, 2009; Butz \& Oelert, 1995). The studied VR was obtained from a mixture of Colombian heavy crude oils.

\section{EXPERIMENTAL SECTION}

\section{Thermal Cracking}

The VR was obtained from a mixture of Colombian crude oils in a vacuum distillation unit. The VR was di- 
luted in 1-methylnaphthalene up to 10 per cent in weight. The reactor used for the thermal cracking experiments was constructed with stainless steel and a volume of $12.5 \mathrm{~mL}$ with dimensions of $120 \mathrm{~mm}$ (length) by $6.5 \mathrm{~mm}$ (diameter), and was operated in steady state regimen at pressures up to $3.0 \mathrm{MPa}$ (Inert blanket maintained for these experiments). Reactor temperatures used in the experiments were digitally controlled at 673, 693 and $713 \mathrm{~K}$. At each temperature, sample fluxes along the reactor were maintained at $4.8,7.5$ and $14.8 \mathrm{~mL}$ per hour, giving residence times of 10, 20 and 30 minutes, respectively.

\section{Asphaltenes Extraction}

After VR samples were thermal cracked under selected experimental conditions, they were fractionated by the ASTM Standard Test Method for Determination of Asphaltenes (Heptane Insolubles) in Crude Petroleum and Petroleum Products (ASTM D6560-12) to extract the asphaltenes. All the asphaltene samples were concentrated and dried at $333 \mathrm{~K}$, under an inert atmosphere $\left(N_{2}\right)$, until no changes in weight were registered.

\section{Elemental Analysis}

Asphaltenes were characterized by elemental analysis: carbon, hydrogen, nitrogen (ASTM D5291-10/ ASTM D5373-08), and sulfur (ASTM D4239-12). The results are reported in Table1.

\section{Nuclear Magnetic Resonance Spectroscopy}

The ${ }^{1} \mathrm{H}$ - and ${ }^{13} \mathrm{C}$-NMR spectra were obtained with a Bruker AMX spectrometer at 300 and $75.47 \mathrm{MHz}$, respectively. $4 \% \mathrm{wt} / \mathrm{wt}$ sample solutions prepared in $\mathrm{CDCl}_{3}(99.8 \% \mathrm{D})$ were analyzed via ${ }^{1} \mathrm{H}-\mathrm{NMR} .30^{\circ}$ pulses (Bruker zg30 pulse sequence) were used, and the delay time was $2 \mathrm{~s}$ (sweep width $3900.25 \mathrm{~Hz}$ ). Sixteen scans were averaged for each spectrum. 10\% $\mathrm{wt} / \mathrm{wt}$ sample solutions in $\mathrm{CDCl}_{3}(99.8 \% \mathrm{D})$ were analyzed via ${ }^{13} \mathrm{C}$-NMR, using $\mathrm{Cr}(\mathrm{acac})_{3}$ as paramagnetic relaxation reagent at a $0.05 \mathrm{M}$ concentration. The $30^{\circ}$ pulses (Bruker zgig30 pulse sequence) were used, with a delay time of 20 seconds (sweep width $16666.67 \mathrm{~Hz}$ ). 3000 scans were averaged for each spectrum. In both cases, spectra were recorded using a $5 \mathrm{~mm}$ probe with a spinning rate of $10 \mathrm{~Hz}$ and a temperature of 298.15 $\mathrm{K}$. ${ }^{1} \mathrm{H}$ - and ${ }^{13} \mathrm{C}$-NMR spectra of asphaltenes from the reference VR sample are shown in Figures 1 and 2 respectively, noticing that these spectra look like many others reported in literature.

NMR data were processed using the standard procedure as follows: free induction decays were apodized using exponential windows with a weight factor of 1 , followed by the Fourier transform, zero- and one-order phase, and base line correction. Finally, the selected areas, accordingly with the areas of the procedure previously reported by the authors (Poveda \& Molina, 2012), were integrated and normalized. The procedure was

Table 1. Elemental analysis of asphaltenes samples.

\begin{tabular}{|c|c|c|c|c|c|c|c|c|c|c|}
\hline \multirow{3}{*}{$\begin{array}{c}\text { Elemental } \\
\text { Analysis }\end{array}$} & \multirow{3}{*}{ Uncracked } & \multicolumn{9}{|c|}{ Reaction Time and Temperature (K) } \\
\hline & & \multicolumn{3}{|c|}{$10 \mathrm{~min}$} & \multicolumn{3}{|c|}{$20 \min$} & \multicolumn{3}{|c|}{$30 \mathrm{~min}$} \\
\hline & & 673 & 693 & 713 & 673 & 693 & 713 & 673 & 693 & 713 \\
\hline$\%$ C & 81.8 & 82.6 & 83.7 & 84.8 & 85.4 & 85.7 & 86.0 & 86.8 & 87.0 & 88.2 \\
\hline$\% \mathrm{H}$ & 7.58 & 7.16 & 6.25 & 5.68 & 5.26 & 4.89 & 4.59 & 4.03 & 3.56 & 3.26 \\
\hline$\% N$ & 0.85 & 0.86 & 0.85 & 0.82 & 0.86 & 0.91 & 0.85 & 0.86 & 0.56 & 0.41 \\
\hline$\% \mathrm{~S}$ & 8.01 & 8.16 & 7.89 & 7.65 & 7.56 & 8.15 & 8.25 & 8.56 & 8.62 & 8.56 \\
\hline $\mathrm{C} / \mathrm{H}$ & 0.90 & 0.97 & 1.12 & 1.24 & 1.35 & 1.46 & 1.56 & 1.80 & 2.04 & 2.26 \\
\hline
\end{tabular}

Ref. Reference, correspond to the asphaltenes obtained from the virgin VR sample. 
integrated and normalized. The procedure was repeated eight times, average values were calculated and the absolute errors were not higher than $4.5 \%$, as shown in Tables 2 and 3.

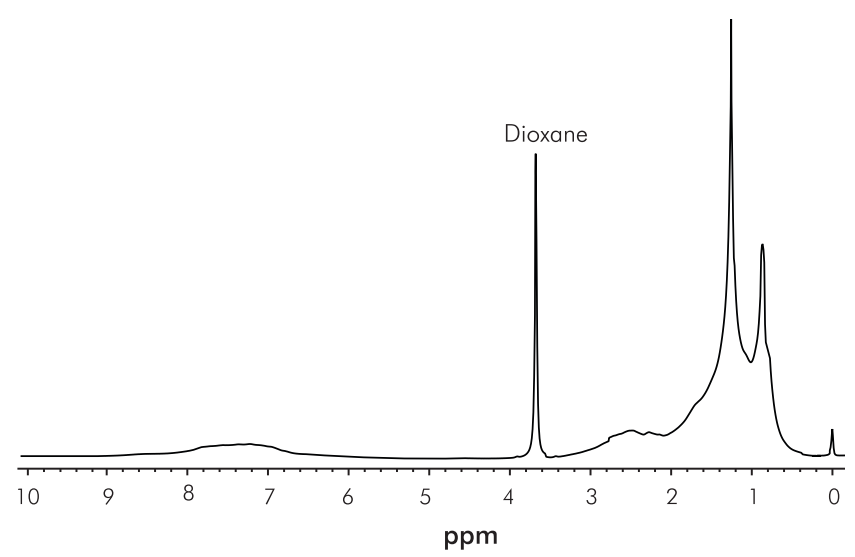

Figure 1. Typical ${ }^{1} \mathrm{H}-\mathrm{NMR}$ spectra of asphaltenes (reference sample) at $300 \mathrm{MHz}$.

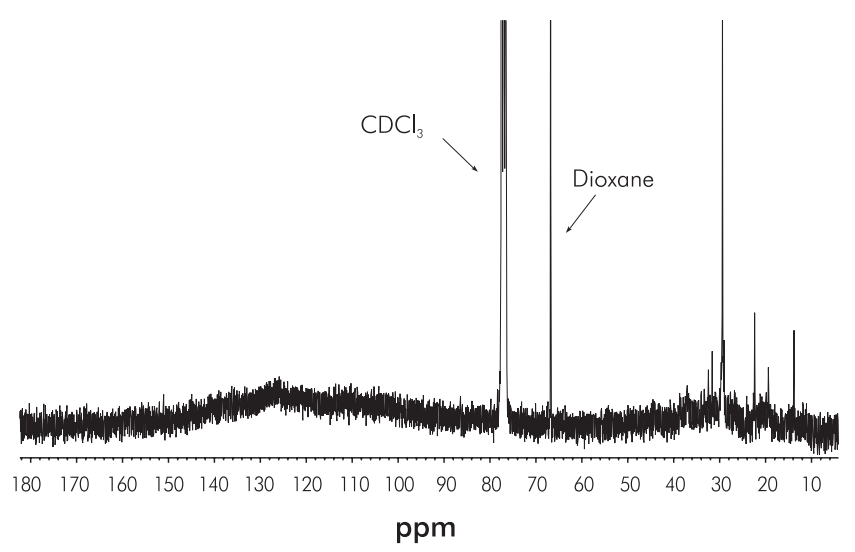

Figure 2. Typical ${ }^{13} \mathrm{C}-\mathrm{NMR}$ spectra of asphaltenes (reference sample) at $75.5 \mathrm{MHz}$.

\section{MOLECULAR CHANGES OF ASPHALTENES AFTER THERMAL CRACKING}

Structural changes of asphaltenes samples obtained after thermal cracking of VRs were analyzed based on the areas of ${ }^{1} \mathrm{H}$ - and ${ }^{13} \mathrm{C}-\mathrm{NMR}$ reported by authors (Poveda \& Molina, 2012). Tables 2 and 3 present the regions in the ${ }^{1} \mathrm{H}$ - and ${ }^{13} \mathrm{C}$-NMR spectra and the average values of calculated areas.

\section{RESULTS AND DISCUSSION}

\section{Physicochemical Characterization and NMR Considerations}

Elemental analysis (Table 1) reveals that as the reaction severity increases, the percentage of carbon and nitrogen increases, while the percentage of hydrogen and sulfur decreases. The changes in the elemental analysis show that chemical changes are occurring during the thermal cracking process. Condensation of the aromatic substructures may increase as the reaction occurs, and the relative percentage of hydrogen decreases as a result of cleavage of the bonds linking paraffinic substructures to the aromatic cores. Produced saturated molecules can be eliminated as gases, and the relative ratio of carbon to hydrogen increases as a consequence of the increment in the relative amount of aromatics. These data play in favor of the elimination of small molecules with relative high amounts of hydrogen as $\mathrm{CH}_{4}, \mathrm{C}_{2} \mathrm{H}_{6}, \mathrm{C}_{3} \mathrm{H}_{8}$, with $\mathrm{CH}$ ratios of $0.25,0.33$ and 0.375 ; respectively. On the other hand, aromatics as benzene $\left(\mathrm{C}_{6} \mathrm{H}_{6}\right)$, naphthalene $\left(\mathrm{C}_{10} \mathrm{H}_{8}\right)$, and coronene $\left(\mathrm{C}_{24} \mathrm{H}_{12}\right)$, show $\mathrm{C} / \mathrm{H}$ ratios of $1.0,1.25$ and 2.0, respectively. Based on the elemental analysis, we can calculate the $\mathrm{C} / \mathrm{H}$ ratio as $(\% \mathrm{C} / 12) /(\% \mathrm{H} / 1)$, reported values are shown in Table 1 . As the severity of thermal cracking increases, $\mathrm{C} / \mathrm{H}$ ratio increases as shown in Figure 3. The calculated $\mathrm{C} / \mathrm{H}$ ratio -for those asphaltenes in the original vacuum residue- show a value of 0.899 , lower than the calculated for benzene. This result suggests that not only aromatics are present in the sample, but also paraffinic chains. As a result, $\mathrm{C} / \mathrm{H}$ values diminish. For the limit case, when longer aliphatic chains are present, the maximum $\mathrm{C} / \mathrm{H}$ value could be 0.5 , which diminishes as the number of carbons decreases. The maximum $\mathrm{C} / \mathrm{H}$ value 2.225 was observed at a reaction time of $30 \mathrm{~min}$, and a temperature of $713 \mathrm{~K}$. The calculated value indicates that asphaltenes condensate as the reaction occurs. It can be argued that changes in the molecular structure start from a low condensed aromatic structure with pendant paraffinic chains, to a higher condensed structure with lower number of side paraffinic chains.

In ${ }^{13} \mathrm{C}$-NMR spectra, unusual chemical shifts of the aromatic carbons were observed. Values between 110 and 160 are common (Asaoka, Nakata, Shiroto 
Table 2. Normalized integrated areas in the 'H-NMR spectra of samples.

\begin{tabular}{|c|c|c|c|c|c|c|c|c|c|c|c|}
\hline \multirow{3}{*}{$\begin{array}{l}\text { Region } \\
\text { (ppm) }\end{array}$} & \multirow{3}{*}{ Uncracked } & \multicolumn{9}{|c|}{ Reaction Time and Temperature (K) } & \multirow{3}{*}{ Group } \\
\hline & & \multicolumn{3}{|c|}{$10 \mathrm{~min}$} & \multicolumn{3}{|c|}{$20 \mathrm{~min}$} & \multicolumn{3}{|c|}{$30 \mathrm{~min}$} & \\
\hline & & 673 & 693 & 713 & 673 & 693 & 713 & 673 & 693 & 713 & \\
\hline$H_{1}(0.1-1.0)$ & 13.97 & 14.92 & 15.53 & 13.38 & 15.71 & 14.04 & 14.71 & 16.19 & 13.89 & 13.96 & $\mathrm{H}_{\mathrm{CH}_{3}}^{\gamma}$ \\
\hline $\mathrm{H}_{2}(1.0-1.5)$ & 27.69 & 26.11 & 26.74 & 19.93 & 24.91 & 20.50 & 22.62 & 23.42 & 21.23 & 19.47 & $\mathrm{H}_{\mathrm{CH}_{3}}^{\beta}, \mathrm{H}_{\mathrm{CH}_{2}}^{\beta}$ \\
\hline $\mathrm{H}_{3}(1.5-2.0)$ & 35.25 & 37.99 & 40.32 & 49.09 & 44.46 & 50.74 & 42.86 & 45.02 & 47.38 & 46.86 & $H_{N}^{\beta}$ \\
\hline $\mathrm{H}_{4}(2.0-4.5)$ & 11.59 & 10.25 & 9.89 & 8.61 & 10.01 & 8.09 & 11.42 & 8.87 & 9.42 & 9.77 & $H_{P, N}^{\alpha}$ \\
\hline $\mathrm{H}_{5}(4.5-6.0)$ & 0.48 & 0.53 & 0.55 & 0.71 & 0.60 & 0.62 & 0.51 & 0.68 & 0.49 & 0.37 & $\mathrm{H}_{\circ}$ \\
\hline $\mathrm{H}_{6}(6.0-7.2)$ & 2.28 & 2.48 & 2.68 & 2.70 & 1.93 & 2.03 & 2.68 & 2.03 & 2.07 & 2.29 & $\mathrm{H}_{\mathrm{Ar}}^{\mathrm{ma}}$ \\
\hline $\mathrm{H}_{7}(7.2-9.0)$ & 8.99 & 7.65 & 4.19 & 5.57 & 2.04 & 3.66 & 5.02 & 3.67 & 5.32 & 7.09 & $\mathrm{H}_{\mathrm{Ar}}^{\mathrm{pa}}$ \\
\hline $\mathrm{H}_{8}(9.0-12.0)$ & 0.08 & 0.08 & 0.11 & 0.09 & 0.34 & 0.33 & 0.20 & 0.14 & 0.20 & 0.20 & $\mathrm{H}_{\text {Ald, Car }}$ \\
\hline
\end{tabular}

Ref. Reference, correspond to the asphaltenes obtained from the virgin VR sample.

Table 3. Normalized integrated areas in the ${ }^{13} \mathrm{C}-\mathrm{NMR}$ spectra of samples.

\begin{tabular}{|c|c|c|c|c|c|c|c|c|c|c|c|}
\hline \multirow{3}{*}{$\begin{array}{l}\text { Region } \\
(\mathrm{ppm})\end{array}$} & \multirow{3}{*}{ Uncracked } & \multicolumn{9}{|c|}{ Reaction Time and Temperature (K) } & \multirow{3}{*}{ Group } \\
\hline & & \multicolumn{3}{|c|}{$10 \mathrm{~min}$} & \multicolumn{3}{|c|}{$20 \mathrm{~min}$} & \multicolumn{3}{|c|}{$30 \mathrm{~min}$} & \\
\hline & & 673 & 693 & 713 & 673 & 693 & 713 & 673 & 693 & 713 & \\
\hline$C_{1}(3.0-18.5)$ & 3.26 & 4.08 & 3.85 & 4.23 & 5.03 & 4.13 & 4.97 & 12.46 & 4.39 & 5.63 & $\mathrm{C}_{\mathrm{Par}-\mathrm{CH}_{3}}$ \\
\hline$C_{2}(18.5-21.5)$ & 2.24 & 2.17 & 1.22 & 5.94 & 3.62 & 2.51 & 2.59 & 1.62 & 0.66 & 0.98 & $\mathrm{C}_{\mathrm{Par}-\mathrm{CH}_{3}}^{\alpha-\mathrm{Ar}_{2}}$ \\
\hline $\mathrm{C}_{3}(21.5-50.0)$ & 16.89 & 15.32 & 14.66 & 17.70 & 19.09 & 19.34 & 18.24 & 17.03 & 13.49 & 10.73 & $C_{N P}$ \\
\hline $\mathrm{C}_{4}(50.0-60.0)$ & 3.58 & 2.26 & 1.57 & 1.81 & 1.43 & 2.23 & 2.47 & 5.41 & 0.99 & 1.48 & $\mathrm{C}_{\mathrm{CH}}, \mathrm{C}_{\mathrm{C}}$ \\
\hline$C_{5}(60.0-78.0)$ & 4.54 & 4.24 & 2.64 & 3.51 & 2.82 & 2.74 & 3.13 & 8.37 & 2.83 & 4.78 & $\mathrm{C}_{\mathrm{OH}}^{\alpha}$ \\
\hline$C_{6}(85.0-129.2)$ & 48.62 & 46.37 & 45.62 & 49.12 & 41.07 & 48.99 & 42.37 & 36.56 & 58.10 & 52.94 & $C_{A r}^{H} C_{C=C}, C_{A A A}$ \\
\hline$C_{7}(129.8-137.0)$ & 4.27 & 5.83 & 9.81 & 5.38 & 6.23 & 4.94 & 6.09 & 2.75 & 2.42 & 4.17 & $\mathrm{C}_{\mathrm{Ar}}^{\mathrm{CH}_{3}}, \mathrm{C}_{\mathrm{AA}}$ \\
\hline$C_{8}(137.0-160.0)$ & 7.29 & 9.70 & 10.79 & 7.65 & 10.58 & 7.57 & 11.18 & 6.41 & 6.21 & 7.76 & $C_{A r}^{S}$ \\
\hline$C_{9}(160.0-220.0)$ & 9.32 & 11.20 & 9.83 & 10.23 & 10.13 & 7.55 & 8.96 & 9.37 & 10.91 & 11.53 & $\mathrm{C}_{\mathrm{Cort}} \mathrm{C}_{\mathrm{Quir}} \mathrm{C}_{\mathrm{Ald}, \mathrm{COt}}$ \\
\hline
\end{tabular}

Ref. Reference, correspond to the asphaltenes obtained from the virgin VR sample.

\& Takeuchi, 1983), but the ${ }^{13} \mathrm{C}-\mathrm{NMR}$ spectra of samples showed chemical shifts up to $82 \mathrm{ppm}$ (Figure 2). The observed chemical shifts can be primarily attributed to some structural reordering in the aromatic substructure. Higher degrees of aromatic condensation can be responsible for strong annular electron currents that produce local induced magnetic fields. These local induced magnetic fields can perturb the chemical shifts observed for small aromatic molecules. The phenomenon of $\pi-\pi$ stacking can also be observed as the concentration of NMR analyzed solutions increase. This allows intermolecular interactions, and the molecular arrangement energetically favors the stabilization of clusters. 


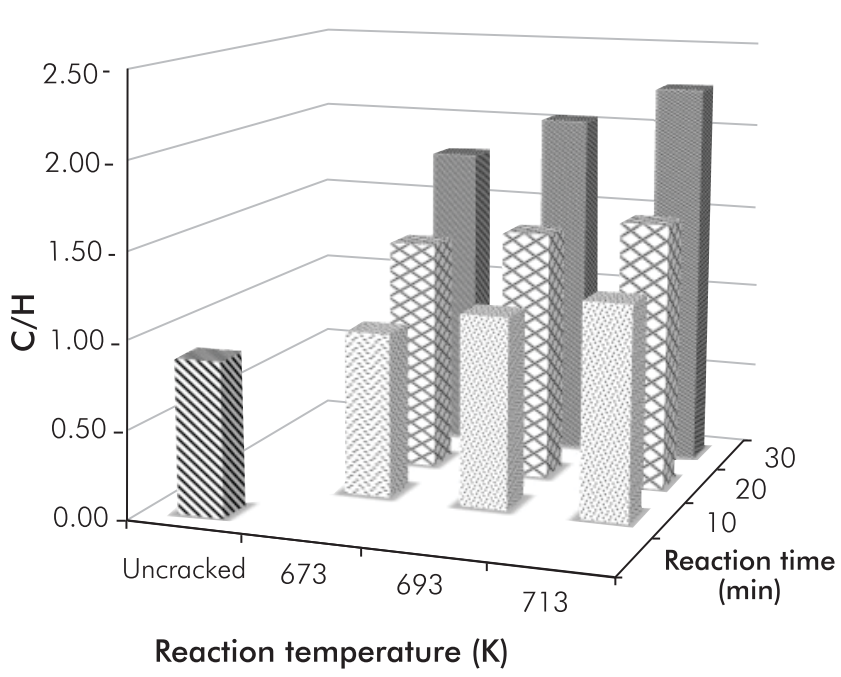

Figure 3. $\mathrm{C} / \mathrm{H}$ ratio of asphaltenes samples.

\section{Structural Characterization of Asphaltenes using NMR Spectroscopy after Thermal Cracking}

Structural changes were followed studying the changes of functional group areas in the ${ }^{1} \mathrm{H}$ - and ${ }^{13} \mathrm{C}-\mathrm{NMR}$ spectra. This allows identifying the main changes in chemical structures occurring during the thermal cracking process. The analysis focused on the structural changes occurring in the aromatic, naphthenic and paraffinic substructures, and how those increased or decreased as function of the reaction variables.

From the ${ }^{1} \mathrm{H}-\mathrm{NMR}$ spectra and integrated areas we can observe that as the severity conditions of thermal cracking increases (residence time and reaction temperature), some areas show particular tendencies, as explained here. For the $H_{1}$ region, were resonances of paraffinic hydrogens appear in $\mathrm{CH}_{3}$ groups, the relative area decreases because thermal treatment reduces the amount of such group, probably by a C-C bond scission. Also, the same tendency was observed in the $\mathrm{H}_{2}$ region, where $\mathrm{H}_{\mathrm{CH}_{3}}^{\beta}$ and $\mathrm{H}_{\mathrm{CH}_{2}}^{\beta}$ hydrogens appear, corresponding to $\mathrm{CH}_{3}$ and $\mathrm{CH}_{2}$ in a $\beta$ position to aromatic rings.

An interesting behavior was observed when the areas of regions $H_{6}$ and $H_{7}$ were analyzed. In these regions, the hydrogens in aromatic systems appear, both monoaromatics and polyaromatics. Integrated areas do not show a general tendency as observed in regions $H_{1}$ and $\mathrm{H}_{2}$. This behavior can be interpreted as many processes at molecular scale take place during cracking. Aromatic cores can change as a consequence either from the elimination of fragments, or capture of saturated carbons in alpha position to the aromatic core. When region $H_{4}$ was analyzed, a correlation between the areas and reaction conditions was not observed.

From a molecular point of view, this behavior could be explained by a two-step mechanism: first, the formation of radicals allows the possible fusion of paraffinic chains to the aromatic cores, forming naphthenic rings; and second, if hydrogen elimination takes place from naphthenic rings, an increase in the number of aromatic rings is possible.

Thermal cracking reactions are one of the most extensively studied processes in heavy fractions such as VRs (Ancheyta et al., 2009). From some experimental results therein published, the structural changes observed in the asphaltenes during thermal cracking are in agreement with the reaction mechanisms reported in the literature (Hayashitani, Bennion, Donnelly \& Moore, 1978). These reaction mechanisms are the scission of C-C and $\mathrm{C}-\mathrm{H}$ bonds, aromatization, alkylation, condensation, and dehydrogenation (Hayashitani et al., 1978).

The structural complexity of asphaltenes makes the analysis of changes of molecular structure really difficult. Therefore, some authors employ model compounds to study the possible changes occurring during thermal cracking (Savage \& Klein, 1987). The asphaltenes consist mainly of a core, or cores of polycondensed aromatic rings with alkyl and naphthenic chains. With the increase in temperature, the $\mathrm{C}-\mathrm{C}$ bond of the pendant chains can be broken, and hydrocarbons of low molecular weight, possibly as gases, are formed. Savage, Klein and Kukes (1985) report that lighter paraffins were formed from secondary reactions of larger saturated chains and not exclusively by primary decomposition of asphaltenes. Secondary reactions involve the cracking of naphthenes and long-chain alkanes.

In this work we observed that the ratio $\mathrm{H}_{\mathrm{Ar}} / \mathrm{H}_{\mathrm{Sat}}$ (Figure 4), where $\mathrm{H}_{\mathrm{Ar}}=\mathrm{H}_{6}+\mathrm{H}_{7}$, and $\mathrm{H}_{\mathrm{Sat}}=\mathrm{H}_{1}+\mathrm{H}_{2}+\mathrm{H}_{3}+\mathrm{H}_{4}$ (Table 2), does not show a clear tendency as a function of reaction time. At a reaction time of 10 minutes, the $\mathrm{H}_{\mathrm{Ar}} /$ $\mathrm{H}_{\text {Sat }}$ ratio does not show a clear behavior but decreases 
comparatively to the uncracked sample. At $673 \mathrm{~K}$, the ratio $\mathrm{H}_{\mathrm{Ar}} / \mathrm{H}_{\mathrm{Sat}}$ is close to 0.113 , decreasing to 0.042 at $693 \mathrm{~K}$, but increasing when temperature reaches 713 $\mathrm{K}$. When reaction times are 20 and 30 minutes, the $\mathrm{H}_{\mathrm{Ar}} \mathrm{l}$ $\mathrm{H}_{\text {Sat }}$ ratio shows a tendency as a function of reaction temperature. At 20 minutes of reaction, the $\mathrm{H}_{\mathrm{Ar}} / \mathrm{H}_{\text {Sat }}$ ratio increases from 0.042 to 0.084 . This behavior shows that asphaltenes of vacuum residue reduce the amount of saturated structures while the aromatics increases. This could be possible when $\mathrm{C}-\mathrm{C}$ bond scissions increase at long reaction times, more than 20 minutes; therefore, parts of aliphatic chains of molecules are eliminated.

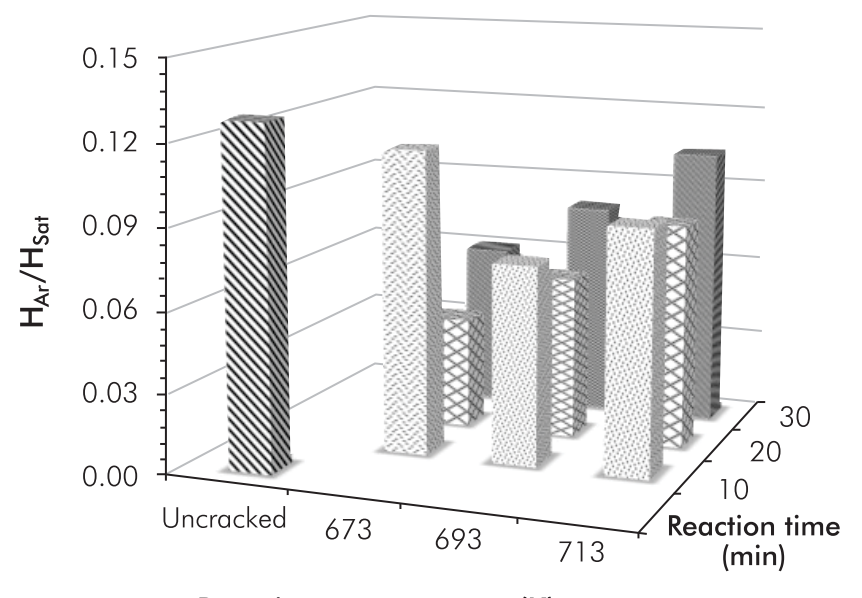

Reaction temperature (K)

Figure 4. $\mathrm{H}_{\mathrm{Ar}} / \mathrm{H}_{\text {Sat }}$ ratio of asphaltenes samples.

When we observe the $\mathrm{C}_{\mathrm{Ar}} / \mathrm{C}_{\mathrm{Sat}}$ ratio (Figure 5), where $\mathrm{C}_{\mathrm{Ar}}=\mathrm{C}_{6}+\mathrm{C}_{7}+\mathrm{C}_{8}$, and $\mathrm{C}_{\mathrm{Sat}}=\mathrm{C}_{1}+\mathrm{C}_{2}+\mathrm{C}_{3}+\mathrm{C}_{4}$, the results are in good agreement with the proposed explanation for the behavior of the $\mathrm{H}_{\mathrm{Ar}} / \mathrm{H}_{\mathrm{Sat}}$ ratio. At low reaction times (10 minutes), the amount of aromatic carbon relative to saturated carbon decreases. At these short times, the molecular processes can be characterized for molecular rearrangements, in order to increase the saturated structures. When reaction times reach 30 minutes, the amount of aromatic carbon increases, in accordance with saturated structures. As the reaction time increases, the reactions allow the formation of aromatics, possibly increasing the size of condensed aromatic units by a mechanism that involves the fusion and dehydrogenation of naphthenic rings to aromatics. Consequently, the size of aromatics rings increases.

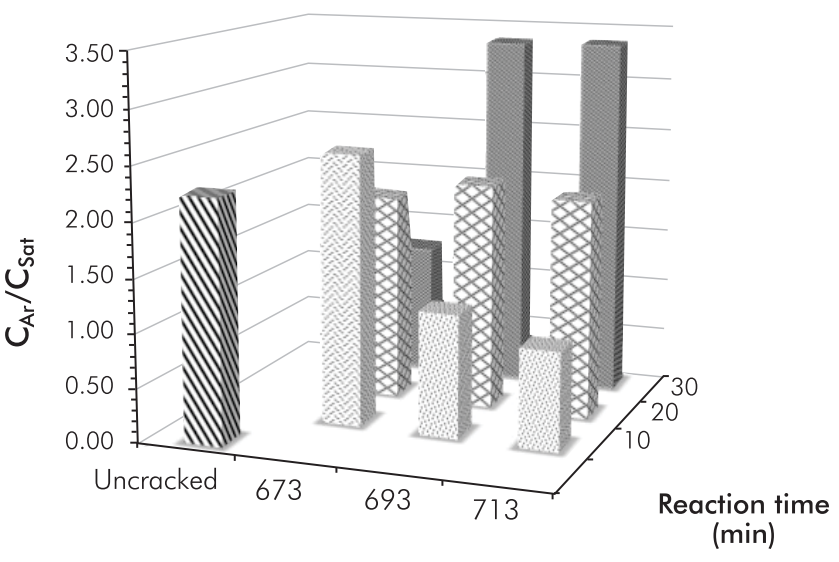

Reaction temperature (K)

Figure 5. $C_{A_{r}} / C_{\text {Sat }}$ ratio of asphaltenes samples.

As was reported by Butz and Oelert (1995), the cracking of asphaltenes at temperatures of 683,708 and $733 \mathrm{~K}$ in a batch reactor shows that the rate of asphaltene conversion decreases continuously with an increase in the reaction time. Despite longer reaction times, the aromatic cores are more difficult to react.

\section{CONCLUSIONS}

- The present work reports the structural changes in asphaltenes observed from thermal cracking a vacuum residue, determined on the basis of the integrated areas in the ${ }^{1} \mathrm{H}$ - and ${ }^{13} \mathrm{C}-\mathrm{NMR}$ spectra. NMR spectroscopic analysis is an affordable technique to understand the molecular changes when heavy crude oils and their fractions are exposed to refinery processes as thermal cracking, catalytic hydrogenation, and others. Under the thermal cracking conditions used in this work, there is an increased reaction in temperatures and reaction times in cleaved asphaltenes, producing light gases and increasing the molecular complexity of asphaltenes remaining after processing. The results indicate that the asphaltenes exposed to thermal cracking increased their aromatic size. Additional experiments and analysis are required to understand the complex reactivity mechanism that takes place when heavy crude oils fractions are exposed to thermal treatments. 


\section{ACKNOWLEDGEMENTS}

The authors would like to thank Escuela de Química at Universidad Industrial de Santander, and Ecopetrol S.A. - Instituto Colombiano del Petróleo for the support to make possible the completion of this work.

\section{REFERENCES}

Ancheyta, J., Trejo, F. \& Rana, M. S. (2009). Hydrocracking and kinetics of asphaltenes. In: Asphaltenes chemical transformation during hydroprocessing of heavy oils. Boca Raton: CRC Press, 329-369.

Andersen, S. I., Oluf Jensen, J. \& Speight, J. (2005). X-ray diffraction of subfractions of petroleum asphaltenes. Energy Fuels, 19(6), 2371-2377.

Asaoka, S., Nakata, S., Shiroto, Y. \& Takeuchi, C. (1983). Asphaltene cracking in catalytic hydrotreating of heavy oils. 2. Study of changes in asphaltene structure during catalytic hydroprocessing. Ind. Eng. Chem. Process. Des. Dev., 22(2), 242-248.

ASTM Standard D6560-12. Test Method for Determination of Asphaltenes (Heptane Insolubles) in Crude Petroleum and Petroleum Products, ASTM International, West Conshohocken, PA, 2012

ASTM Standard D5291-10. Test Method for Instrumental Determination of Carbon, Hydrogen, and Nitrogen in Petroleum Products and Lubricants. ASTM International, West Conshohocken, PA, 2010.

ASTM Standard D5373-08. Test Method for Instrumental Determination of Carbon, Hydrogen, and Nitrogen in Laboratory Samples of Coal. ASTM International, West Conshohocken, PA, 2008.

ASTM Standard D4239-12. Test Method for Sulfur in the Analysis Sample of Coal and Coke Using High-Temperature Tube Furnace Combustion. ASTM International, West Conshohocken, PA, 2012.

Ballard Andrews, A., Guerra, R. E., Mullins, O. C. \& Sen, P. N. (2006). Diffusivity of asphaltene molecules by fluorescence correlation spectroscopy. J. Phys. Chem. A, 110(26), 8093-8097.
Brown, J. K. \& Ladner, W. R. (1960). A study of the hydrogen distribution in coal-like materials by high-resolution nuclear magnetic resonance spectroscopy II. A comparison with infrared measurement and the conversion to carbon structure. Fuel, 39(1), 87-96.

Butz, T. \& Oelert, H. H. (1995). Application of petroleum asphaltenes in cracking under hydrogen. Fuel, 74(11), 1671-1676.

Cantor, D. M. (1978). Nuclear magnetic resonance spectrometric determination of average molecular structure parameters for coal-derived liquids. Anal. Chem., 50(8), 1185-1187.

Dickinson, E. M. (1980). Structural comparison of petroleum fractions using proton and ${ }^{13} \mathrm{Cn}$.m.r. spectroscopy. Fuel, 59(5), 290-294.

Doan, B. T., Gillet, B., Blondel, B. \& Beloiel, J. C. (1995). Analysis of polyaromatics in crude gas oil mixtures: a new strategy using ${ }^{1} \mathrm{H}$ 2D n.m.r. Fuel, 74(12), 1806-1811.

Dosseh, G., Rousseau, B. \& Fuchs, A. H. (1991). Identification of aromatic molecules in intermediate boiling crude oil fractions by 2D n.m.r. spectroscopy. Fuel, 70(5), 641-646.

Eyssautier, J., Levitz, P., Espinat, D., Jestin, J., Gummel, J., Grillo, I. \& Barré L. (2011). Insight into asphaltene nanoaggregate structure inferred by small angle neutron and X-ray scattering. J. Phys. Chem. B., 115(21), 6827-6837.

Gillet, S., Delpuech, J., Valentin, P. \& Escalier, J. C. (1980). Optimum conditions for crude oil and petroleum product analysis by carbon-13 nuclear magnetic resonance spectrometry. Anal. Chem., 52(6), 813-817.

Gupta, P. L., Dogra, P. V., Kuchhal, R. K. \& Kumar, P. (1986). Estimation of average structural parameters of petroleum crudes and coal-derived liquids by ${ }^{13} \mathrm{C}$ and ${ }^{1} \mathrm{H}$ n.m.r. Fuel, 65(4), 515-519.

Hayashitani, M., Bennion, D., Donnelly, J. \& Moore, G. (1978). Thermal cracking models for Athabasca oil sand oil. SPE Annual Fall Technical Conference and Exhibition. Houston. SPE-7549.

Hirsch, E. \& Altgelt, K. H. (1970). Integrated structural analysis. A method for the determination of average structural parameters of petroleum heavy ends. Anal. Chem., 42(12), 1330-1339. 
Hurtado, P., Gámez, F. \& Martínez-Haya, B. (2010). Oneand two-step ultraviolet and infrared laser desorption ionization mass spectrometry of asphaltenes. Energy Fuels, 24(11), 6067-6073.

Knight, S. A. (1967) Analysis of aromatic petroleum fractions by means of absorption mode Carbon-13 N.M.R. Spectroscopy. Chem. Ind., 11: 1920-1923.

Majumdar, R. D., Gerken, M., Mikula, R. \& Hazendonk, P. (2013) Validation of the Yen-Mullins Model of Athabasca oil-sands asphaltenes using solution-state ${ }^{1} \mathrm{H}$ NMR relaxation and 2D HSQC spectroscopy. Energy Fuels, 27(11), 6528-6537.

Poveda, J. C. \& Molina, D. R. (2012). Average molecular parameters of heavy crude oils and their fractions using NMR spectroscopy. J. Petrol. Sci. Eng., 84-85(1), 1-7.

Rodríguez, R., Hovell, I., de Mello, M. B., Middea, A. \& Lopes, A. (2006). Characterization of aliphatic chains in vacuum residues (VRs) of asphaltenes and resins using molecular modelin and FTIR techniques. Fuel Process. Technol., 87(4), 325-333.

Rongbao, L., Zengmin, S. \& Bailing, L. (1988). Structural analysis of polycyclic aromatic hydrocarbons derived from petroleum and coal by ${ }^{13} \mathrm{C}$ and ${ }^{1} \mathrm{H}-$-n.m.r. spectroscopy. Fuel, 67(4), 565-569.

Rousseau, B. \& Fuchs, A. H. (1989). Determination of average molecular weights of high-boiling aromatic oil fractions by ${ }^{13} \mathrm{C}$ and ${ }^{1} \mathrm{H}$ nuclear magnetic resonance. Fuel, 68(9), 1158-1165.

Savage, P. E. \& Klein, M. T. (1987). Asphaltene reaction pathways. 2. Pyrolysis of n-pentadecylbenzene. Ind. Eng. Chem. Res., 26(3), 488-494.
Savage, P. E., Klein, M. T. \& Kukes, S. (1985). Asphaltene reaction pathways. 1. Thermolysis. Ind. Eng. Chem. Process Des. Dev., 24(4), 1169-1174.

Väänänen, T., Koskela, H., Hiltunen, Y. \& Ala-Korpela, M. (2002). Application of quantitative artificial neural network analysis to 2D NMR spectra of hydrocarbon mixtures. J. Chem. Inf. Model., 42(6), 1343-1346.

Yasar, M., Trauth, D. M. \& Klein, M. T. (2001). Asphaltene and resid pyrolysis. 2. The effect of reaction environment on pathways and selectivities. Energy Fuels, 15(3), 504-509.

Yokoyama, S., Uchino, H., Katoh, T., Sanada, Y. \& Yoshida T. (1981). Combination of ${ }^{13} \mathrm{C}$ - and ${ }^{1} \mathrm{H}$-n.m.r. spectroscopy for structural analyses of neutral, acidic and basic heteroatom compounds in products from coal hydrogenation. Fuel, 60(3), 254-262.

\section{AUTHORS}

\section{Juan Carlos Poveda}

Affiliation: Universidad Industrial de Santander

Chemist, Universidad Industrial de Santander

Ph.D. in Chemistry, Universidad Nacional Autónoma de México

e-mail: jcpoveda@uis.edu.co

\section{Daniel Ricardo Molina}

Affiliation: Universidad Industrial de Santander Chemist, Universidad Industrial de Santander $\mathrm{Ph} . \mathrm{D}$. in Chemistry, Universidad Industrial de Santander e-mail: dmolina@uis.edu.co

\section{Edgar Francisco Pantoja Agreda}

Affiliation: Corporación para la Investigación de la Corrosión Chemical Engineering, Universidad Nacional de Colombia M. Sc. in Chemical Engineering, Universidad Industrial de Santander

e-mail: pantoja.francisco@gmail.com 


\section{NOTATION}

$\mathrm{H}_{\mathrm{CH}_{3}}^{\gamma} \quad$ Paraffinic hydrogen $\mathrm{CH}_{3}$ type, $\gamma$ and more to aromatic structures

$\mathrm{H}_{\mathrm{CH}_{3}}^{\beta}, \mathrm{H}_{\mathrm{CH}}^{\beta}$ Hydrogens in $\mathrm{CH}_{3}$ and $\mathrm{CH}_{2}, \beta$ to aromatic systems

$\mathrm{H}_{\mathrm{N}}^{\beta} \quad$ Naphthenic hydrogens, $\beta$ to aromatic systems

$\mathrm{H}_{\mathrm{P}, \mathrm{N}}^{\alpha} \quad$ Paraffinic and naphthenic hydrogens $\mathrm{CH}, \mathrm{CH}_{2}$ and $\mathrm{CH}_{3}$ type,

linked to aromatics systems in $\alpha$ position

$\mathrm{H}_{\mathrm{O}} \quad$ Hydrogens in olefins

$\mathrm{H}_{\mathrm{Ar}}^{\mathrm{ma}} \quad$ Hydrogens in monoaromatics

$\mathrm{H}_{\mathrm{Ar}}^{\mathrm{pa}} \quad$ Hydrogens in polyaromatics

$\mathrm{H}_{\text {Ald, Car }}$ Hydrogens in aldehyde and carboxylic groups

$\mathrm{C}_{\mathrm{Par}_{-} \mathrm{CH}_{3}} \quad \mathrm{CH}_{3}$ Carbons

$\mathrm{C}_{\mathrm{Par}-\mathrm{CH}_{3}}^{\alpha-\mathrm{Ar}} \quad$ Methyl carbons in alpha position to aromatic rings

$\mathrm{C}_{\mathrm{NP}} \quad$ Naphthenic and paraffinic carbons, $\mathrm{CH}_{2}$ and $\mathrm{CH}$ type

$\mathrm{C}_{\text {Par-CH }} \quad$ Tertiary $(\mathrm{CH})$ paraffinic carbons

$\mathrm{C}_{\text {Par-C }} \quad$ Quaternary paraffinic carbons

$\mathrm{C}_{\mathrm{OH}}^{\alpha} \quad$ Carbons joined to hydroxil groups

$\mathrm{C}_{\mathrm{Ar}}^{\mathrm{H}} \quad$ Protonated aromatic carbon

$\mathrm{C}_{\mathrm{C}=\mathrm{C}} \quad$ Unsaturated carbons in olephins

$\mathrm{C}_{\mathrm{AAA}} \quad$ Pericondensed carbons

$\mathrm{C}_{\mathrm{Ar}}^{\mathrm{CH}_{3}} \quad$ Aromatic carbons joined to methyl groups

$\mathrm{C}_{\mathrm{AA}} \quad$ Catacondensed carbons

$\mathrm{C}_{\mathrm{Ar}}^{\mathrm{S}} \quad$ Aromatic carbons alpha to sulfur atoms

$\mathrm{C}_{\text {Car }} \quad$ Carboxilix carbons

$\mathrm{C}_{\text {Qui }} \quad$ Quinolinic carbons

$\mathrm{C}_{\text {Ald, Cet }} \quad$ Aldehydic and cetonic carbons 